\section{Nazarenko I., Dedov 0.}

\title{
INVESTIGATION OF COMPLEX STRUCTURE SYSTEMS BASED ON SPECTRAL ANALYSIS
}

Об’єктом досліджень є процес обробки результатів руху віброущільнюючих машин будівельної індустрії. Однією з проблем при дослідженні вібраційних машин технологічного призначення є визначення параметрів просторового руху робочих органів машини та встановлення відповідності їх з розрахунковими, які отримані в результаті розрахунків чи чисельного моделювання. А також при встановленні технічного стану конструкцій під дією складного динамічного впливу. Труднощі, які виникають при дослідженні динамічних прочесів, викликані визначенням природи і фактичних значень дисипативних сил, впливом невідомих випадкових величин, в тому числі, завад і недосконалостей вимірювальної техніки.

Підхід, який пропонується у даній роботі, базується на гіпотезі про розгляд системи складної структури, що має динамічний вплив, як єдиної системи із відповідними ій динамічними характеристиками. Реалізація такого підходу може бути здійснена шляхом визначення динамічних параметрів системи з подальшим спектральним аналізом та встановленням основних частот коливань, які обумовлені зовнішнім впливом, а також виявлення та чіткої ідентифікащї вищих гармонік. Для визначення необхідного ефективного методу представлення результатів були використані записи безперервної фіксащії вібраційного процесу із відомою частотою зовнішнього впливу. Подальша обробка таких результатів на основі спектральнокореляційного методу дозволила визначити ефективний спосіб визначення основної частоти, виявити вплив вищих гармонік та сторонніх частот, які непритаманні досліджуваному процесу. Розглянуті спектри коливань в лінійній та логарифмічній шкалі за прискоренням та спектральною потужністю. За результатами дослідження встановлено, що застосування саме спектральної потужності рівня сигналу $\epsilon$ ефективним методом визначення динамічного процесу та виконання інтегральної оцінки загальної системи.

Отримані результати досліджень можуть бути використані при дослідженні систем із складним рухом при невідомих параметрах зовнішнього впливу при виконанні діагностування та оцінки технічного стану машин технологічного призначення, коливань несучих і огороджувальних конструкцій споруд.

Ключові слова: спектр коливань, власні частоти коливань, динамічне навантаження, вібрачійна діагностика, спектральна потужність.

\section{Introduction}

Vibration machines and processes occupy a significant place in various sectors of the economy. Along with the study of dynamic phenomena that occur directly during the implementation of the technological process, an urgent task is to assess the impact of such equipment on neighboring structures. In the general case, it is possible to talk about a system that is subject to the general laws of motion. But at the same time, given the complexity of the system, the number of its structural elements and the variations of their possible vibrations, studying the parameters of such systems is a rather difficult task.

The behavior of vibration systems subject to random forces must be studied by the same methods of representing both random effects themselves and random reactions of vibration systems to these effects. Vibration analysis is one of the experimental methods for assessing the technical condition and identifying defects in dynamic systems. As a rule, when applying this method, spectral analysis based on the Fourier transform is used, with which vi- bration frequencies are determined. And based on the values of the obtained vibration frequencies, a further assessment is made about the technical condition of the object under study and the presence of defects. Difficulties arising in the study of complex technical systems by this method associated with establishing the nature of random influences and an unambiguous interpretation of the analysis results. Since next to the actual physical processes that are inherent in the system under study there are false analysis results associated with errors in the mathematical apparatus, imperfections of measuring instruments and the influence of external factors of a random nature.

Experimental studies based on measurements of accelerations are given in [1,2]. In these works, on the basis of the constructed vibration spectrum, the natural frequencies of vibrations are determined. The technique described can be used in the study of more complex dynamic systems. Measurements of the dynamic characteristics of systems for the purpose of diagnosis and monitoring of existing defects in metal structures are presented in [2]. 
The methodology for the application of experimental studies of vibration and their processing is presented. The improvement of the calculation model based on the obtained dynamic characteristics is proposed.

Measurements of the dynamic characteristics of systems in order to identify defects in structural elements are devoted to $[3,4]$. In these works, a methodology for the application of experimental studies of vibration and their processing is presented. The authors note the presence of noise phenomena that interfere with the assessment and accounting of these phenomena, it is proposed to implement using mathematical processing. The work [5] is devoted to the application of the method in nonlinear active vibration control systems. As the authors note, the advantage of such an integral method is that there is no need to know the parameters of the system, such as mass, attenuation, and stiffness coefficients, which are usually obtained by finite element methods. For measuring vibrations, acceleration sensors are usually used. But at the same time, there are alternative solutions. The remote measurement given in [6] is based on the use of laser and optical devices. And the use of an vibration sensor based on optical fiber is proposed in [7]. Of course, such data acquisition systems are highly accurate and sensitive. The work [8] presents the results of experimental studies of conveyor rollers based on Wavelet analysis, which is effective in the study of non-stationary processes with a change in frequency characteristics. The obtained results of theoretical [9] and experimental [10] studies of the shaping surfaces of a technological vibration machine indicate a complex movement of such a system, and the authors recommend the use of spectral analysis to process the obtained data. Despite the large number of publications on this subject, the question of assessing dynamic characteristics is relevant, since in most cases it depends on the particular system under study and the conditions for the use of measuring equipment. Thus, the object of research is the process of processing the results of the movement of vibration-stabilizing machines in the construction industry. And the aim of research is determination of an effective method for identifying a dynamic process and performing an integral assessment of the overall system.

\section{Methods of research}

Experimental studies were performed on the created experimental model [10] with the known parameters for the excitation of spatial vibrations, which are implemented using a centrifugal exciter. The frequency of the applied force was monitored by the unbalance position sensor and amounted to $17.5 \mathrm{~Hz}$.

To measure the vibration parameters, a triaxial accelerometer is used, which is included in the ZET 048C seismic station kit (Russia). The implementation of spectral analysis was performed using the ZETLAB SEISMO software, using the discrete Fourier transform method for processing continuous records of a dynamic process.

\section{Research results and discussion}

Based on the conducted experimental studies, a number of vibrograms characteristic of the system under study are obtained. Records of continuous fixation of the parameters of the dynamic effect directly on the forming surfaces at an external force frequency of $17.5 \mathrm{~Hz}$ are shown in Fig. 1.

As can be seen from the vibrogram in Fig. 1, there are other vibration frequencies that differ in numerical value from the main one.

The resulting spectrum of the RMS value of the measured parameter of the reduced vibrogram (Fig. 2) indicates the presence of higher harmonics. It should be noted that the second peak in the spectrum $(35 \mathrm{~Hz})$ has a greater numerical value than the first $(17.5 \mathrm{~Hz})$.

Therefore, in the case of an unknown numerical value of the fundamental frequency, a false result could be obtained by taking the second peak as the fundamental frequency, and the first as its subharmonic. The presence of peaks at higher frequencies is also doubtful. So, a clear peak at a frequency of $50 \mathrm{~Hz}$ is a consequence of the influence of external noise from the power grid. Other values of frequencies can be both superharmonics of the fundamental frequency and the result of mathematical processing.

The spectrum of the RMS value of the measured parameter in the logarithmic scale of the same process (Fig. 3) has a completely different character. There are a large number of peaks of both frequencies that occur in the dynamic process and frequencies due to external noise $(50,100,150 \mathrm{~Hz})$. Therefore, for a process which dynamic parameters are unknown, it is difficult to determine the values that take place.

Unlike the previous spectra, the spectrum of vibrations with respect to the spectral power parameter (Fig. 4) clearly demonstrates the presence of only three peaks. Moreover, the main frequency of vibration excitation $(17.5 \mathrm{~Hz})$ corresponds to a larger numerical value, its higher harmonics (second and third peak in the spectrum) correspond to the real physical process, which is shown in Fig. 1.

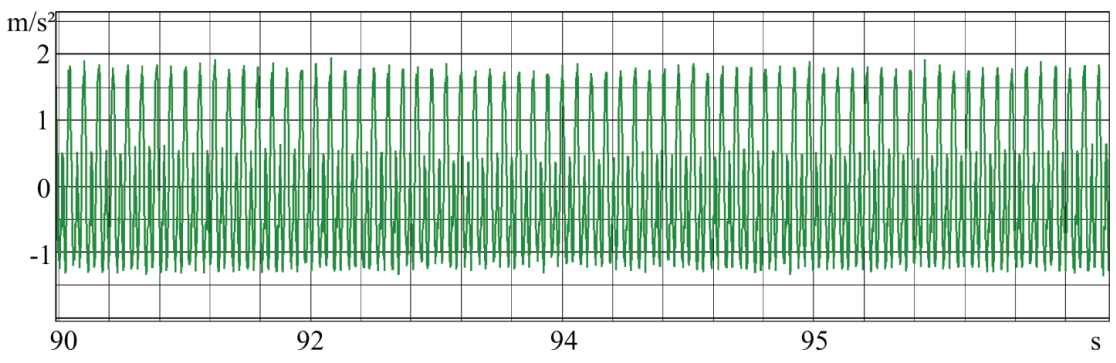

Fig. 1. Vibrogram of the investigated process

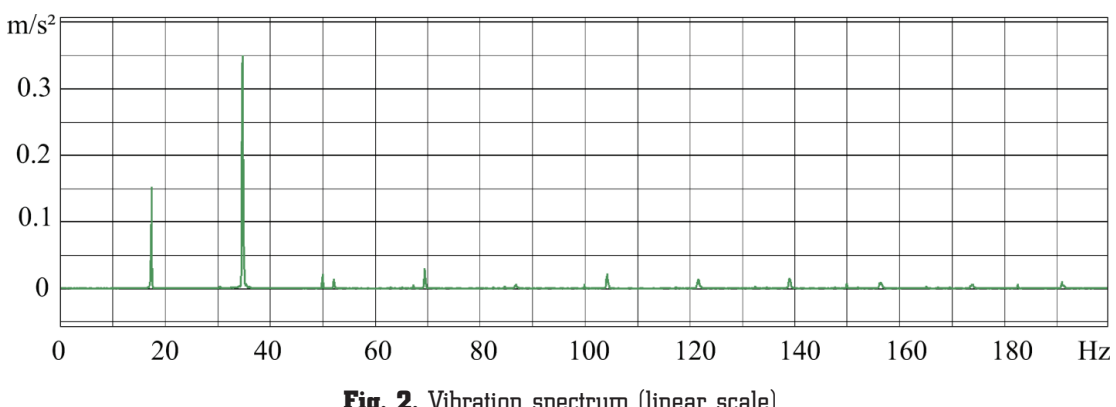

Fig. 2. Vibration spectrum (linear scale) 

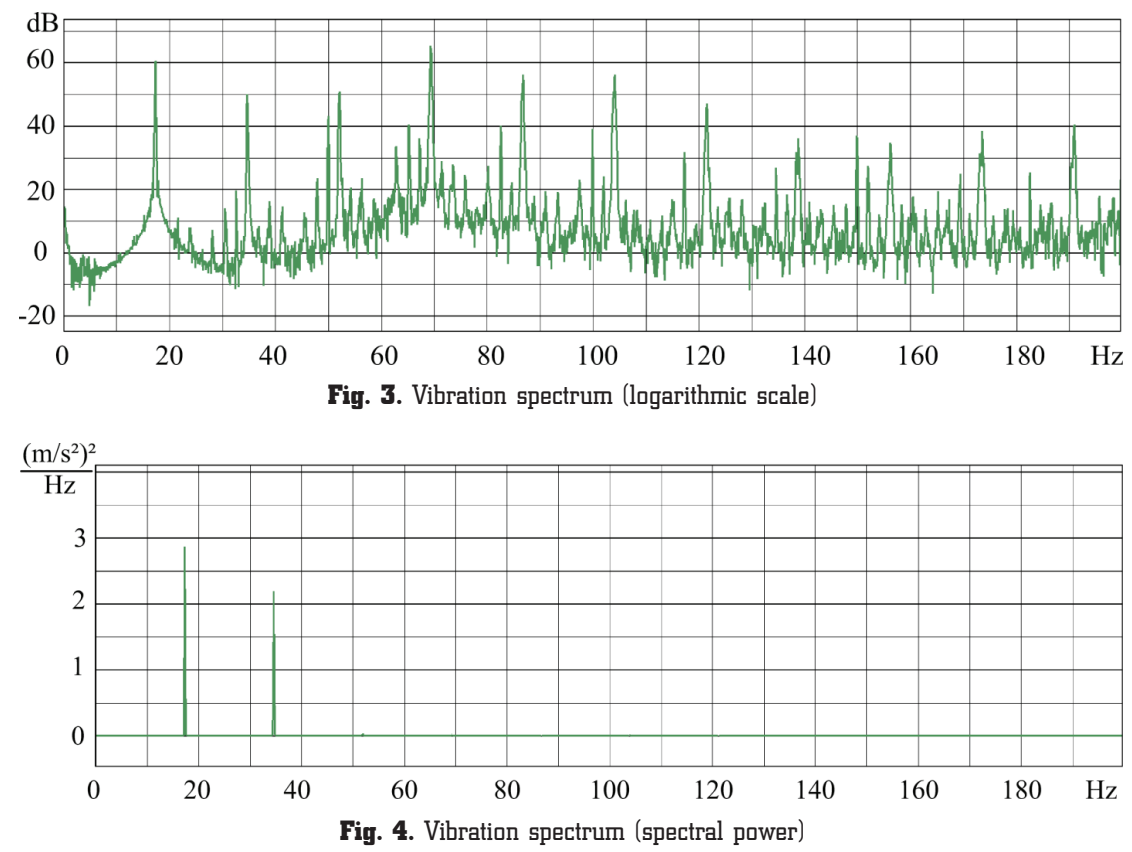

The performed studies confirm the possibility of the effective use of spectral analysis for assessing dynamic processes and can be used in monitoring the technical condition of technical structures with unknown external exposure parameters. Evaluation criteria, such as spectral power and spectral density, can be used for an adequate analysis, identifying the fundamental vibration frequencies, their harmonics and allow to take into account the effect of higher harmonics on the investigated process.

\section{Conclusions}

It is found that the vibration spectra in the linear and logarithmic scales with acceleration are considered do not make it possible to evaluate the real dynamic process. The spectral power spectrum more adequately reflects the investigated process and allows to estimate the contribution of higher harmonics to the system dynamics.

The obtained research results can be used in the study of systems with complex motion with unknown parameters of external influence when performing diagnostics and evaluating the technical condition of technological machines, the vibrations of the supporting and enclosing structures of buildings.

\section{References}

1. Kavyanpoor, M., Shokrollahi, S. (2019). Dynamic behaviors of a fractional order nonlinear oscillator. Journal of King Saud University - Science, 31 (1), 14-20. doi: http://doi.org/10.1016/ j.jksus.2017.03.006

2. Jia, Y., Seshia, A. A. (2014). An auto-parametrically excited vibration energy harvester. Sensors and Actuators A: Physical, 220, 69-75. doi: http://doi.org/10.1016/j.sna.2014.09.012

3. Patel, V. N., Tandon, N., Pandey, R. K. (2014). Vibrations Generated by Rolling Element Bearings having Multiple Local Defects on Races. Procedia Technology, 14, 312-319. doi: http:// doi.org/10.1016/j.protcy.2014.08.041
4. Giagopoulos, D., Arailopoulos, A., Dertimanis, V., Papadimitriou, C., Chatzi, E., Grompanopoulos, K. (2017). Computational Framework for Online Estimation of Fatigue Damage using Vibration Measurements from a Limited Number of Sensors. Procedia Engineering, 199, 1906-1911. doi: http://doi.org/ 10.1016/j.proeng.2017.09.424

5. Ghandchi Tehrani, M., Wilmshurst, L., Elliott, S. J. (2013) Receptance method for active vibration control of a nonlinear system. Journal of Sound and Vibration, 332 (19), 4440-4449. doi: http://doi.org/10.1016/j.jsv.2013.04.002

6. Lezhin, D. S., Falaleev, S. V., Safin, A. I., Ulanov, A. M., Vergnano, D. (2017). Comparison of Different Methods of Non-contact Vibration Measurement. Procedia Engineering, 176, 175-183. doi: http://doi.org/10.1016/j.proeng.2017.02.286

7. Gianti, M. S., Prasetyo, E., Wijaya, A. D., Berliandika, S., Marzuki, A. (2017). Vibration Measurement of Mathematical Pendulum based on Macrobending-Fiber Optic Sensor as a Model of Bridge Structural Health Monitoring. Procedia Engineering, 170, 430-434. doi: http://doi.org/10.1016/j.proeng.2017.03.069

8. Bendjama, H., Bouhouche, S., Boucherit, M. S. (2012). Application of Wavelet Transform for Fault Diagnosis in Rotating Machinery. International Journal of Machine Learning and Computing, 2 (1), 82-87. doi: http://doi.org/10.7763/ ijmlc.2012.v2.93

9. Nazarenko, I., Gaidaichuk, V., Dedov, O., Diachenko, O. (2017). Investigation of vibration machine movement with a multimode oscillation spectrum. Eastern-European Journal of Enterprise Technologies, 6 (1 (90)), 28-36. doi: http://doi.org/10.15587/17294061.2017.118731

10. Nazarenko, I., Dedov, O., Svidersky, A., Oryshchenko, S. (2018). Experimental studies of forming design at dynamic load. Technology Audit and Production Reserves, 6 (1 (44)), 8-13. doi: http:// doi.org/10.15587/2312-8372.2018.151735

Nazarenko Ivan, Doctor of Technical Sciences, Professor, Head of Department of Machinery and Equipment of Technological Processes, Kyiv National University of Construction and Architecture, Ukraine, e-mail: inazar@i.ua, ORCID: http://orcid.org/0000-0002-1888-3687

Dedov Oleg, PhD, Associate Professor, Department of Machinery and Equipment of Technological Processes, Kyiv National University of Construction and Architecture,Ukraine, e-mail: dedovvcbk@ukr.net, ORCID: http://orcid.org/0000-0001-5006-772X 